\title{
Proposals To Unify the Genera Bartonella and Rochalimaea, with Descriptions of Bartonella quintana comb. nov., Bartonella vinsonii comb. nov., Bartonella henselae comb. nov., and Bartonella elizabethae comb. nov., and To Remove the Family Bartonellaceae from the Order Rickettsiales
}

\author{
DON J. BRENNER, ${ }^{1 *}$ STEVEN P. O'CONNOR, ${ }^{2}$ HERBERT H. WINKLER, ${ }^{3}$ \\ AND ARNOLD G. STEIGERWALT ${ }^{1}$ \\ Emerging Bacterial and Mycotic Diseases Branch, ${ }^{1}$ and Respiratory Diseases Branch, ${ }^{2}$ Division of Bacterial \\ and Mycotic Diseases, National Center for Infectious Diseases, Centers for Disease Control and Prevention, \\ Atlanta, Georgia 30333, and Department of Microbiology and Immunology, University of South Alabama, \\ Mobile, Alabama $36688^{3}$
}

\begin{abstract}
DNA hybridization data (hydroxyapatite method, 50 to $70^{\circ} \mathrm{C}$ ) indicate that Rickettsia prowazekii, the type species of the type genus of the family Rickettsiaceae, is substantially less closely related to Rochalimaea species than was previously thought. The levels of relatedness of Rickettsia prowazekii to Rochalimaea species and to Bartonella bacilliformis under optimal conditions for DNA reassociation were 0 to $14 \%$, with $25.5 \%$ or greater divergence in related sequences. When stringent reassociation criteria were used, the levels of relatedness were 0 to $2 \%$. The genera Bartonella and Rochalimaea are currently classified in different families (the Bartonellaceae and the Rickettsiaceae) in the order Rickettsiales. On the basis of DNA relatedness data, previous 16S rRNA sequence data, guanine-plus-cytosine contents, and phenotypic characteristics, neither Bartonella bacilliformis nor Rochalimaea species are closely related to other organisms currently classified in the order Rickettsiales. In fact, the closest relative of these organisms is Brucella abortus. It is therefore proposed that the family Bartonellaceae should be removed from the order Rickettsiales. Previous 16S rRNA sequence data and DNA hybridization data revealed high levels of relatedness between Bartonella bacilliformis and the four Rochalimaea species, indicating that these species are members of a single genus. It is proposed that the genus Rochalimaea should be united with the genus Bartonella in the family Bartonellaceae. The name Bartonella is retained as the genus name since it has nomenclatural priority over the name Rochalimaea. This means that new combinations for the Rochalimaea species must be created. Proposals are therefore made for the creation of Bartonella quintana comb. nov., Bartonella vinsonii comb. nov., Bartonella henselae comb. nov., and Bartonella elizabethae comb. nov.
\end{abstract}

All organisms considered to be rickettsiae are classified in the order Rickettsiales, which presently contains the three families Rickettsiaceae, Bartonellaceae, and Anaplasmataceae $(54,56)$. Rickettsiae were originally defined as parasites that could grow only in their hosts or in living tissues (30). Members of the genera Bartonella and Grahamella in the family Bartonellaceae (36) and the genus Rochalimaea in the family Rickettsiaceae (57), however, are cultivable on bacteriologic media.

Bartonella bacilliformis is the only Bartonella species that has been described previously (21). Forty or more species of the genus Grahamella have been described $(21,48)$, although only two species have been validly published and no cultures exist for these species (22). Until recently, Rochalimaea quintana and Rochalimaea vinsonii were the only Rochalimaea species that had been described (57). Two new species isolated from human clinical sources, Rochalimaea henselae and Rochalimaea elizabethae, were described recently (11, $31,58)$.

Substantial efforts to determine the phylogenetic position of rickettsiae began with the 16S rRNA sequencing studies of Weisburg and his colleagues $(49,50,52)$. In other recent studies workers described new Rochalimaea species and further determined the phylogenetic relationships of Roch-

\footnotetext{
* Corresponding author.
}

alimaea and Bartonella species to each other and to members of the family Rickettsiaceae $(6,9,26,31,33-35,58)$. The data obtained in these studies do not support the present classification of the genera Bartonella and Rochalimaea in the order Rickettsiales or the classification of these taxa in different families. Furthermore, the data indicate that the five species currently in these genera should be in a single genus. In this paper we describe DNA hybridization data which reveal the levels of relatedness of Rickettsia prowazekii to members of the genera Rochalimaea and Bartonella. We also review the classification of these taxa, discuss the previous data which indicate that this classification should be changed, and make the following taxonomic proposals: (i) that the genus Rochalimaea should be transferred from the family Rickettsiaceae to the family Bartonellaceae; (ii) that the genus Rochalimaea should be united with the genus Bartonella; (iii) that Rochalimaea species should be transferred to the genus Bartonella as Bartonella quintana comb. nov., Bartonella vinsonii comb. nov., Bartonella henselae comb. nov., and Bartonella elizabethae comb. nov.; and (iv) that the family Bartonellaceae should be removed from the order Rickettsiales.

\section{MATERIALS AND METHODS}

Bacterial strains. Type strains Rochalimaea quintana ATCC VR-358 and Rochalimaea vinsonii ATCC VR-152 
were obtained from the American Type Culture Collection and were provided by Ted Tzianabos, Viral and Rickettsial Zoonoses Branch, Division of Viral and Rickettsial Diseases, National Center for Infectious Diseases, Centers for Disease Control and Prevention. Rochalimaea henselae type strain G5436 (= Houston 1 = ATCC 49793), Rochalimaea elizabethae type strain F9251 (= B-91-002005 = ATCC 49927), Bartonella bacilliformis type strain KC 583 (= ATCC 35685), and Brucella melitensis type strain KC 1414 (= ATCC 23456) were obtained from the culture collection of the Special Bacteriology Laboratory, Emerging Bacterial and Mycotic Diseases Branch, Division of Bacterial and Mycotic Diseases, National Center for Infectious Diseases, Centers for Disease Control and Prevention. These organisms were cultivated on Trypticase soy agar supplemented with 5\% defibrinated sheep blood or on heart infusion agar supplemented with $5 \%$ defibrinated rabbit blood at $37^{\circ} \mathrm{C}$ for 5 to 7 days. Rickettsia prowazekii Madrid E (= VR-233) from yolk sac passage 280 was cultivated in 6-day-old embryonated and antibiotic-free hen eggs (Truslow Farms, Chestertown, Md.); 8 days later, the rickettsiae were harvested and purified as described previously (59). Rickettsia prowazekii was further purified by using a variation of Renografin density gradient centrifugation $(13,18)$ in which the rickettsiae were suspended in $218 \mathrm{mM}$ sucrose- $3.76 \mathrm{mM} \mathrm{KH}_{2} \mathrm{PO}_{4-}^{-}$ $7.1 \mathrm{mM} \mathrm{K}_{2} \mathrm{HPO}_{4}-5 \mathrm{mM}$ glutamic acid ( $\mathrm{pH} 7.0$ ), layered onto $25 \%$ Renografin (E. R. Squibb, Inc., Princeton, N.J.), and sedimented by centrifugation at $30,240 \times g$ for $60 \mathrm{~min}$ at $4^{\circ} \mathrm{C}$ in an SA-600 rotor (Du Pont Sorvall, Inc., Norwalk, Conn.).

DNA hybridization. The methods used to obtain purified DNA and to determine levels of DNA relatedness in free solutions by the hydroxyapatite method have been described previously (8); $60 \mu \mathrm{g}$ of unlabeled DNA per ml instead of 150 $\mu \mathrm{g}$ of unlabeled DNA per ml was used in all hybridization reactions. This was because of the small genome size of these organisms and the scarcity of Rickettsia prowazekii DNA. The reaction kinetics were not significantly changed. DNAs from Rickettsia prowazekii and Rochalimaea quintana were labeled enzymatically in vitro with $\left[{ }^{32} \mathrm{P}\right] \mathrm{dCTP}$ by using a nick translation reagent kit (GIBCO BRL, Gaithersburg, Md.). To obtain optimal reassociation, reaction mixtures containing labeled Rickettsia prowazekii DNA were incubated at $50^{\circ} \mathrm{C}$, and reaction mixtures containing labeled Rochalimaea quintana DNA were incubated at $55^{\circ} \mathrm{C}$. This was because Rickettsia prowazekii has a lower guanine-pluscytosine $(\mathrm{G}+\mathrm{C})$ content than Rochalimaea quintana. Stringent reassociation reaction mixtures were incubated at 65 and $70^{\circ} \mathrm{C}$. The level of divergence in related sequences was estimated to be approximately $1 \%$ for each $1^{\circ} \mathrm{C}$ of decreased thermal stability in a heterologous reassociated DNA duplex compared with the thermal stability of the homologous reassociated DNA duplex. Levels of divergence were calculated to the nearest $0.5 \%$.

16S rRNA sequence analysis. All of the $16 \mathrm{~S}$ rRNA sequences used in this study were retrieved electronically from the GenBank data base (5) (Table 1). The sequences were aligned with the multisequence alignment program PILEUP, which is part of the GOG software package (14). The alignment was masked to remove variable regions where the nucleotide positions could not be reliably determined. This reduced the number of positions included in the analysis to 1,317. Phylogenetic relationships were inferred from the data by using version 3.4 of the PHYLIP software package (17). Evolutionary distance values determined by the method of Jukes and Cantor (19) were used to calculate the rRNA similarity values shown in Tables 2 and 3 and to construct the dendrogram in Fig. 1 by the neighbor-joining method (37). The reliability of the tree was analyzed by bootstrapping the data (16).

Nucleotide sequence accession numbers. The nucleotide sequence accession numbers for the organisms which we studied are shown in Table 1.

\section{RESULTS}

DNA hybridization data are shown in Table 4. Labeled DNA from Rickettsia prowazekii was 6 to $14 \%$ related to unlabeled DNAs from Rochalimaea species and Bartonella bacilliformis. The levels of divergence in related sequences were 26.5 to $27.5 \%$. The levels of relatedness of Rickettsia prowazekii to Rochalimaea and Bartonella species were 0 to $1 \%$ in $65^{\circ} \mathrm{C}$ reactions and 1 to $2 \%$ in $70^{\circ} \mathrm{C}$ reactions. Labeled Rochalimaea quintana DNA exhibited $0 \%$ relatedness to Rickettsia prowazekii DNA in reactions performed at $55^{\circ} \mathrm{C}$. The levels of relatedness of labeled Rickettsia prowazekii and Rochalimaea quintana DNAs to unlabeled DNA from Brucella melitensis were 0 and $1 \%$, respectively.

The dendrogram in Fig. 1 was inferred by the neighborjoining method, using the sequence from Desulfovibrio desulfuricans as the outgroup. The overall topology of the tree agrees with the results of previous phylogenetic studies based on 16S rRNA sequence data. The two Chlamydia species were not found to be closely related to eubacteria that cluster in the Proteobacteria branch $(51,61)$. Among the members of the Proteobacteria branch, organisms previously determined to be members of the $\alpha$ or $\tau$ subgroup were found to cluster together. The three species which form the group at the top of Fig. 1 have been identified as members of the $\tau$ subgroup $(27,50,51,61)$. The 34 representatives of the $\alpha$ subgroup were on a single branch that was divided into two major clusters. With the exception of the four Rochalimaea species and Bartonella bacilliformis, one cluster was composed of all of the species in the order Rickettsiales for which sequence data were available at the time that this study was performed. The eight Ehrlichia species were distributed into three well-delineated groups. Ehrlichia risticii and Ehrlichia sennetsu formed a deeply branching group (group I). Group II consisted of Ehrlichia canis, Ehrlichia ewingii, Ehrlichia chaffeensis, and Cowdria ruminatium, and group III contained Ehrlichia phagocytophila, Ehrlichia equi, "Ehrlichia platys," and Anaplasma marginale. Wolbachia pipientis occupied an intermediate position in the evolution of these species. The three Rickettsia species formed a monophyletic group (group IV) which diverged prior to the 11 species contained in groups I through III.

A second cluster of the $\alpha$ subgroup of Proteobacteria contained all of the species that we propose should be removed from the order Rickettsiales, including the four Rochalimaea species and Bartonella bacilliformis. In this cluster, Rochalimaea species and Bartonella bacilliformis formed a coherent subcluster (group V) that was on a branch with Brucella abortus and Agrobacterium tumefaciens.

A bootstrap analysis of the data was performed to measure the reliability of the polyphyletic nature of the Rickettsiales shown in Fig. 1. A consensus tree derived from the 100 trees generated by this analysis had exactly the same structure as the tree shown in Fig. 1, with the single exception that the positions of $E$. canis and $E$. chaffeensis were interchanged. Groups I through $\mathrm{V}$ were absolutely stable, occurring as shown in Fig. 1 in 100\% of the bootstrapping trials. The overall structure of the cluster consisting of the majority of the Rickettsiales was also very stable, with the taxonomic 
TABLE 1. List of organisms included in the phylogenetic analysis

\begin{tabular}{|c|c|c|c|}
\hline Species & Strain $^{a}$ & Accession no. & Reference(s) \\
\hline \multicolumn{4}{|l|}{ Anaplasmataceae } \\
\hline Anaplasma manginale & & M60313 & 49 \\
\hline \multicolumn{4}{|l|}{ Bartonellaceae } \\
\hline Bartonella bacilliformis & ATCC $35685^{T^{C}}$ & M65249 & 11,26 \\
\hline \multicolumn{4}{|l|}{ Rickettsiaceae (Rickettsieae) } \\
\hline Coxiella burnetii & Q117 & M21291 & 50 \\
\hline Rickettsia prowazekii & Brein $1^{\mathrm{T}}$ & M21789 & 50 \\
\hline Rickettsia rickettsii & ATCC VR- $891^{\mathrm{T}}$ & M21293 & 50 \\
\hline Rickettsia typhi & Wilmington $^{\mathrm{T}}$ & M20499 & 50 \\
\hline Rochalimaea elizabethae & ATCC $49927^{T}$ & L01260 & 11 \\
\hline Rochalimaea henselae & ATCC $49882^{\mathrm{T}}$ & M73229 & 31 \\
\hline Rochalimaea quintana & ATCC VR-358 ${ }^{\mathrm{T}}$ & M73228 & 31 \\
\hline Rochalimaea vinsonii & ATCC VR- $152^{\mathrm{T}}$ & L01259 & 11 \\
\hline \multicolumn{4}{|l|}{ Rickettsiaceae (Ehrlichieae) } \\
\hline Cowdria ruminantium & Crystal Springs & X61659 & 12 \\
\hline Ehrlichia canis & Oklahoma & M73221 & 2 \\
\hline Ehrlichia chaffeensis & & M73222 & 2 \\
\hline Ehrlichia equi & & M73223 & 2 \\
\hline Ehrlichia ewingii & Stillwater ${ }^{\mathrm{T}}$ & M73227 & 3 \\
\hline Ehrlichia phagocytophila & Old Sourhope & M73220 & 2 \\
\hline 'Ehrlichia platys"' & & M82801 & 3 \\
\hline Ehrlichia risticii & ATCC VR-986 ${ }^{\mathbf{T}}$ & M21290 & 50 \\
\hline Ehrlichia sennetsu & Miyayama & M73219 & 2 \\
\hline \multicolumn{4}{|l|}{ Rickettsiaceae (Wolbachieae) } \\
\hline Wolbachia persica & ATCC VR-331 ${ }^{\mathrm{T}}$ & M21292 & 50 \\
\hline Wolbachia pipientis & & $\mathrm{X} 61768$ & 27 \\
\hline \multicolumn{4}{|l|}{ Chlamydiaceae } \\
\hline Chlamydia psittaci & $6 \mathrm{BC}^{\mathrm{T}}$ & M13769 & 51 \\
\hline Chlamydia trachomatis & 434 & M59178 & \\
\hline \multicolumn{4}{|l|}{ Other $\alpha$ subgroup Proteobacteria } \\
\hline Afipia felis & ATCC $53690^{T}$ & M65248 & 26 \\
\hline Agrobacterium tumefaciens & DMS 30105 & M11223 & 62 \\
\hline Azospirillum lipoferum & ATCC $29707^{\mathrm{T}}$ & M59061 & \\
\hline Brucella abortus & $11-19$ & X13695 & 15 \\
\hline Erythrobacter longus & $\mathrm{OCH} 101^{\mathrm{T}}$ & M96744 & \\
\hline Hyphomicrobium vulgare & MC-750 & X53182 & \\
\hline Methylobacterium extorquens & NCIMB $9399^{\mathrm{T}}$ & M95656 & 7 \\
\hline Methylobacterium organophilum & $\mathrm{XX}^{\mathrm{T}}$ & M29028 & 42 \\
\hline Pseudomonas diminuta & ATCC $11568^{T}$ & M59064 & \\
\hline Rhodopseudomonas acidophila & $7050^{\mathrm{T}}$ & M34128 & \\
\hline Rhodopseudomonas globiformis & ATCC $35887^{\mathrm{T}}$ & M59066 & \\
\hline Rhodopseudomonas palustris & $\mathrm{GH}$ & M59068 & \\
\hline Rhodospirillum fulvum & ATCC $15798^{\mathrm{T}}$ & M59065 & \\
\hline Rhodospirillum molischianum & ATCC $14031^{T}$ & M59067 & \\
\hline Rhodospirillum salexigens & $\operatorname{DSM} 2132^{\mathrm{T}}$ & M59070 & \\
\hline \multicolumn{4}{|l|}{ Subgroup y Proteobacteria } \\
\hline Legionella pneumophila & $\operatorname{ATCC} 33152^{\mathrm{T}}$ & M59157 & \\
\hline \multicolumn{4}{|l|}{ Subgroup y Proteobacteria } \\
\hline Desulfovibrio desulfuricans & ATCC 27774 & M34113 & 29 \\
\hline
\end{tabular}

${ }^{a}$ For each strain for which a strain designation is not given, the template DNA used for sequencing was obtained by enzymatic amplification of 16S rRNA genes from Renografin-purified cells, clinical specimens, or tissue obtained from insect hosts.

${ }^{b}$ For each strain for which a reference is not given, the sequence was submitted to GenBank as "unpublished."

c $\mathrm{T}=$ type strain.

units occurring to the right of the interior nodes present at levels of $95 \%$ or greater. The values for the interior nodes in the other $\alpha$ subgroup of Proteobacteria cluster were generally lower; however, the group consisting of Agrobacterium tumefaciens, Brucella abortus, Bartonella bacilliformis, and the Rochalimaea species occurred in $100 \%$ of the trials.

Table 2 shows the 16S rRNA similarity values for Agrobacterium tumefaciens, Brucella abortus, and members of the Rickettsiales. The sequences of Coxiella burnetii and Wolbachia persica did not exhibit high levels of homology to any of the $\alpha$ subgroup of Proteobacteria sequences, which is consistent with the position of these organisms outside this subgroup. The sequence of $W$. pipientis exhibited the highest levels of homology (approximately $89.5 \%$ ) to the sequences of species belonging to groups II and III. The sequence of Bartonella bacilliformis was most similar to the sequences of the Rochalimaea species, with levels of similarity ranging from 98.7 to $98.8 \%$. These values were only slightly less than the values of 99.1 to $99.8 \%$ obtained in comparisons among the four Rochalimaea species. The sequences of Bartonella bacilliformis and the Rochalimaea species were substantially more similar to the sequences of Brucella abortus and Agrobacterium tumefaciens than to the sequences of members of the Rickettsiales. 
TABLE 2. 16S rRNA similarity matrix

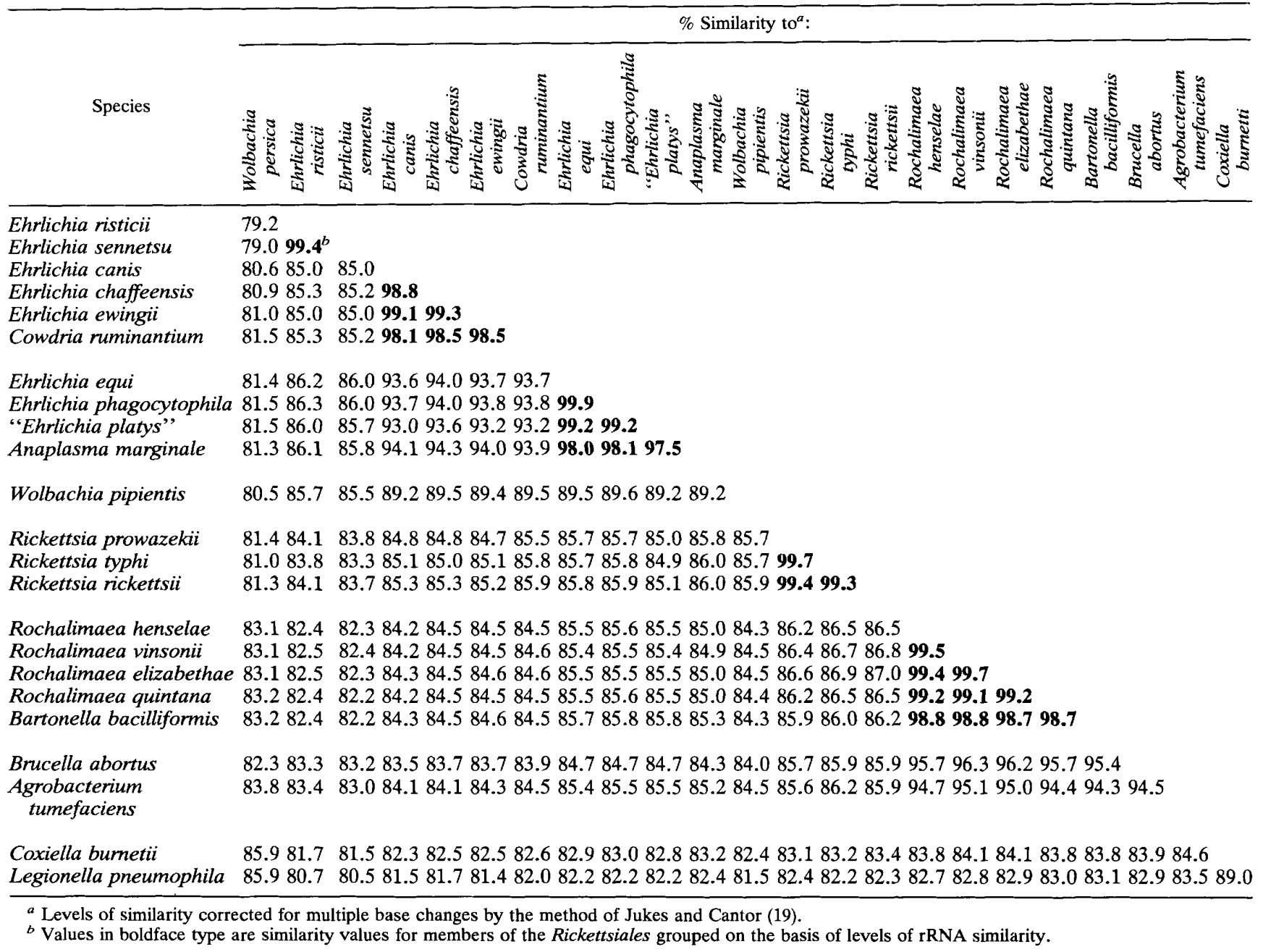

The coherence among the members of the five groups defined above and the distinctiveness of these groups are evident from the intra- and intergroup similarity values shown in Table 3. Within each of the five groups, the average similarity values are high, ranging from 98.7 to $99.5 \%$. When comparisons are made across groups, the average similarity values are approximately $10 \%$ lower, except for groups II

TABLE 3. Levels of $16 \mathrm{~S}$ rRNA similarity among groups of the Rickettsiales

\begin{tabular}{lccccc}
\hline \multirow{2}{*}{ Group } & \multicolumn{5}{c}{ \% Similarity to: } \\
\cline { 2 - 6 } & Group I $^{a}$ & Group II $^{b}$ & Group III $^{c}$ & Group IV $^{d}$ & Group Ve $^{e}$ \\
\hline I & 99.4 & & & & \\
H & 85.1 & 98.7 & & & \\
III & 86.0 & 93.7 & 98.7 & & \\
IV & 83.8 & 85.2 & 85.6 & 99.5 & \multirow{2}{*}{ V } \\
\hline
\end{tabular}

${ }^{a}$ E. risticii and $E$. sennetsu.

${ }^{b}$ E. canis, E. chaffeensis, E. ewingii, and Cowdria ruminantium.

'E. equi, E. phagocytophila, "E. platys," and Anaplasma marginale.

${ }^{d}$ Rickettsia prowazekii, Rickettsia typhi, and Rickettsia rickettsii.

e Rochalimaea henselae, Rochalimaea vinsonii, Rochalimaea elizabethae, Rochalimaea quintana, and Bartonella bacilliformis. and III, whose members exhibit an average level of similarity of $93.7 \%$.

\section{DISCUSSION}

The order Rickettsiales has been a repository for small, gram-negative, usually intracellular, parasitic or mutualistic bacteria, almost all of which are unable to grow on bacteriologic media. These organisms have included rickettsiae, parasites of protozoa, endosymbionts of insects, and, until 1971, chlamydiae $(30,41)$.

As defined by Weiss and Moulder (56), the members of the Rickettsiales are usually rod-shaped or coccoid, often pleomorphic, parasitic or mutualistic, gram-negative, nonmotile bacteria with typical bacterial cell walls. They multiply by binary fission and are cultivable only in their host cells or in living tissues. Except for binary fission, there are notable exceptions to all of these characteristics. The parasitic forms are often associated with arthropods that act as vectors or primary hosts.

Specialists have long recognized the difficulties in accurately classifying the Rickettsiales, as well as its families, genera, and species $(28,43,47,53 a, 54,60)$. Since most rickettsiae could not be grown in vitro, their classification was based heavily on their hosts, their intracellular morphol- 


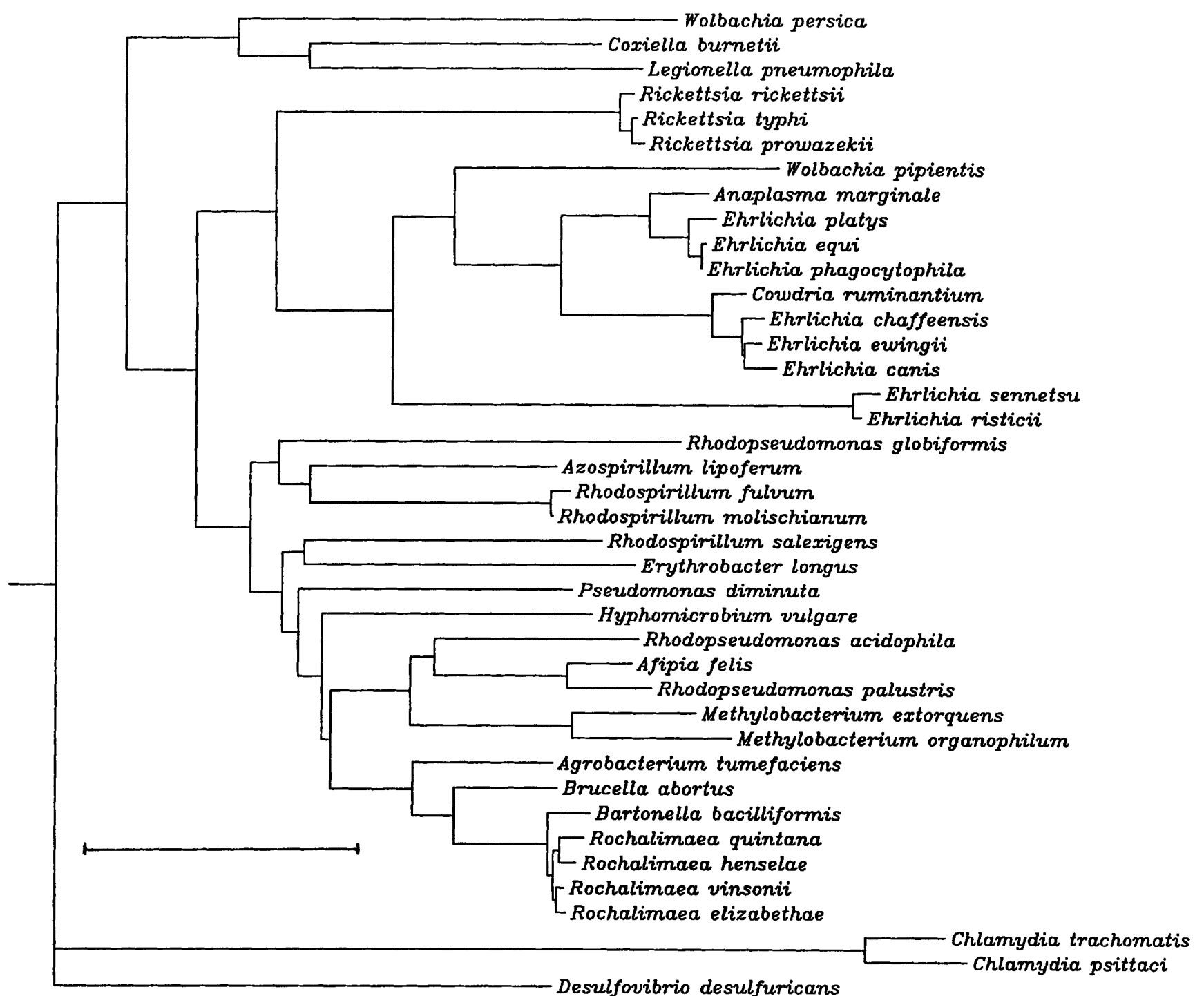

FIG. 1. Phylogenetic tree for members of the order Rickettsiales, members of the order Chlamydiales, and other species representing the $\alpha$ and $\tau$ subgroups of the class Proteobacteria. The sequence of $D$. desulfuricans ( $\sigma$ subgroup of the Proteobacteria) was used as an outgroup. The tree was reconstructed as described in Materials and Methods. The scale bar (lower left) represents a 5\% difference in nucleotide sequences, as determined by taking the sum of all branch lengths that connect two species. GenBank accession numbers and references for the sequences included are given in Table 1.

ogy and locations, their arthropod vectors, their antigenic differences, and a small number of other phenotypic characteristics (43). Another barrier to accurate classification was the fact that the important human and animal pathogens were studied in much more detail than were agents that had little or no effect on their hosts (54).

Rickettsiologists realized that in-depth taxonomic studies were not possible until molecular methods could be used to determine genetic relatedness among rickettsial species and the relatedness of rickettsiae to other bacteria. Tyeryar et al. (43) stated the need "to establish an objective index of genetic relatedness among rickettsiae" and took the first step in doing so by determining $\mathrm{G}+\mathrm{C}$ contents in rickettsial DNAs. In 1982, Weiss (53) wrote, "What we hope to learn in the next decade is the identity of the next-of-kin of rickettsiae by analysis of ribosomal RNA nucleotide sequences or amino acid sequences in ribosomal proteins. This informa- tion will greatly enhance our understanding of the place of rickettsiae in the microbiological world." Ormsbee (28), after reviewing $\mathrm{G}+\mathrm{C}$ content and genome size data, concluded that the major rickettsial groups exhibited substantial divergence. He believed that most of the characteristics common to these major groups were the result of convergent evolution in response to the common pressures of a parasitic or commensal life style. Wisseman (60) came to a similar conclusion, stating that the "organisms so conveniently considered collectively in the past as 'rickettsial agents of human disease' . . . show enormous diversity of properties, actions and host cell associations and . . . may actually be of diverse origins showing both convergent and divergent evolution-e.g., Rochalimaea, Rickettsia, and Coxiella."

Most recently, Kreier and his colleagues (21) concluded that, "Bartonella and Grahamella of the family Bartonellaceae are typical bacteria with cell walls morphologically 
TABLE 6. DNA relatedness data for Rickettsia, Rochalimaea, and Bartonella species

\begin{tabular}{|c|c|c|c|c|c|c|c|c|c|c|c|c|c|c|c|}
\hline \multirow{3}{*}{ Species } & \multicolumn{14}{|c|}{ \% Relatedness to: } & \multirow{3}{*}{ 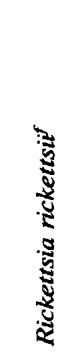 } \\
\hline & \multirow{2}{*}{ 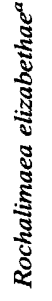 } & \multicolumn{2}{|c|}{$\begin{array}{l}\text { Rochalimaea } \\
\text { henselae }\end{array}$} & \multicolumn{3}{|c|}{$\begin{array}{c}\text { Rochalimae }^{a} \\
\text { quintana }\end{array}$} & \multicolumn{2}{|c|}{$\begin{array}{c}\text { Rochalimae }^{a} \\
\text { vinsonii }\end{array}$} & \multirow{2}{*}{ 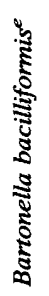 } & \multirow[b]{2}{*}{ 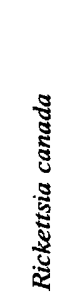 } & \multicolumn{2}{|c|}{$\begin{array}{l}\text { Rickettsia } \\
\text { prowazekii }\end{array}$} & \multicolumn{2}{|c|}{$\begin{array}{c}\text { Rickettsia } \\
\text { typhi }\end{array}$} & \\
\hline & & $\begin{array}{l}\frac{0}{\pi} \\
\text { ज़ } \\
\frac{0}{0} \\
\frac{0}{0}\end{array}$ & $\begin{array}{l}\frac{\dot{\sigma}}{\pi} \\
\frac{0}{0} \\
\frac{\lambda}{\pi}\end{array}$ & $\begin{array}{l}\frac{a}{\sigma} \\
\frac{0}{0} \\
\frac{0}{0} \\
\frac{0}{0} \\
3\end{array}$ & 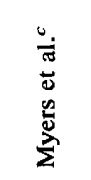 & 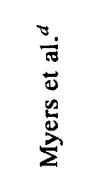 & 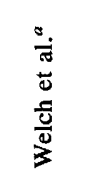 & 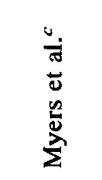 & & & 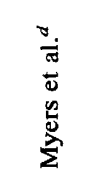 & 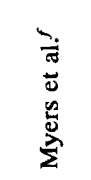 & 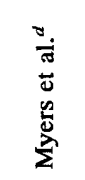 & 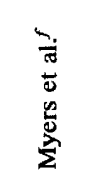 & \\
\hline $\begin{array}{l}\text { Rochalimaea elizabethae } \\
\text { Rochalimaea henselae }\end{array}$ & 67 & $\begin{array}{r}100, \\
100, \\
100 \\
99, \\
98, \\
92, \\
92^{g}\end{array}$ & $\begin{array}{c}49 \\
100 \\
100 \\
99 \\
92^{8}\end{array}$ & $\begin{array}{c}71, \\
69, \\
68, \\
68, \\
67, \\
67, \\
66, \\
62, \\
62^{g}\end{array}$ & & & $\begin{array}{l}64, \\
63, \\
58^{8}\end{array}$ & & & & & & & & \\
\hline Rochalimaea quintana & 59 & 66 & & 100 & $\begin{array}{l}97, \\
94 \\
92^{g}\end{array}$ & 94 & 55 & $\begin{array}{l}42, \\
39, \\
34, \\
31, g\end{array}$ & & & $\begin{array}{l}33, \\
31^{g}\end{array}$ & & $\begin{array}{l}31, \\
27^{8}\end{array}$ & & \\
\hline Rochalimaea vinsonii & 66 & 55 & & 62 & $\begin{array}{l}42, \\
39 \\
34, \\
31^{g}\end{array}$ & & & 100 & & & & & & & \\
\hline Bartonella bacilliformis & 32 & 43 & 47 & 45 & & & & & 97 & & & & & & \\
\hline Rickettsia canada & & & & & & & & & & & & 37 & & 41, & 47 \\
\hline Rickettsia prowazekii & & & & & & & & & & 37 & $\begin{array}{r}100 \\
100 \\
97 \\
94 \\
93 \\
938\end{array}$ & & $\begin{array}{r}78, \\
73, \\
70^{5}\end{array}$ & & 53 \\
\hline Rickettsia typhi & & & & & & $\begin{array}{l}31, \\
\quad 27^{g}\end{array}$ & & & & 52 & $\begin{array}{c}78, \\
73 \\
72 \\
72 \\
70^{5}\end{array}$ & $\begin{array}{c}100 \\
97^{8}\end{array}$ & & & $\begin{array}{l}27, \\
20^{g}\end{array}$ \\
\hline Rickettsia rickettsii & & & & & & & & & & $\begin{array}{l}39, \\
378\end{array}$ & & 47, & & ${ }_{36^{8}}$ & \\
\hline
\end{tabular}

${ }^{a}$ Data from reference 58 .

${ }^{b}$ Data from reference 11 .

$c$ Data from reference 25 .

${ }^{d}$ Data from reference 23 .

e Data from reference 9.

${ }^{f}$ Data from reference 24 .

${ }^{g}$ More than one relatedness percentage under a species name indicates that multiple strains or multiple methods were used to obtain data.

Rochalimaea quintana and found that this organism belongs in the $\alpha-2$ subgroup of the Proteobacteria and that its $16 \mathrm{~S}$ rRNA sequence is most homologous $(92.5 \%)$ with that of Agrobacterium tumefaciens. Weisburg and his collaborators (50) subsequently sequenced the $16 \mathrm{~S}$ rRNAs of six additional species belonging to the Rickettsiaceae. Rickettsia prowazekii and Rickettsia typhi 16S rRNAs were 99.5\% homologous and were 98.2 and $98.5 \%$ homologous, respectively, to Rickettsia rickettsii $16 \mathrm{~S}$ rRNA. The Rickettsia species were in the $\alpha$ subgroup of the Proteobacteria, but not in the $\alpha-2$ subgroup with Rochalimaea quintana. In fact, E. risticii was more closely related to Rickettsia prowazekii than was Rochalimaea quintana. Coxiella burnetii and $W$. persica were in the $\tau$ subgroup, with members of the genus Coxiella being specifically, although not extremely closely, related to Legionella pneumophila. These data leave no doubt that there is substantial heterogeneity within the family Rickettsiaceae and the tribe Rickettsieae, which contains the genera Rickettsia, Rochalimaea, and Coxiella.

The polyphyletic nature of the order Rickettsiales and the family Rickettsiaceae was confirmed, and additional taxonomic problems were identified as more rickettsial $16 \mathrm{~S}$ rRNAs were sequenced. The genus Ehrlichia was shown to contain three very different groups $(2,3)$. E. ewingii, $E$. chaffeensis, and $E$. canis form one group whose members are $98 \%$ interrelated. This group is about $92 \%$ related to a second group consisting of $E$. equi, E. phagocytophila, and "E. platys" and about $84 \%$ related to the third group, which 
contains $E$. risticii and $E$. sennetsu. Cowdria ruminatium was about $97 \%$ homologous to $E$. chaffeensis and $E$. canis (45) and was more closely related to members of the genus Anaplasma in the family Anaplasmataceae than to species belonging to the Rickettsiaceae, the family in which it is currently classified (12).

Another example is Anaplasma marginale, which exhibited higher levels of homology to members of the Rickettsiaceae (Rickettsia species and E. risticii) than were observed with members of genera in the Rickettsiaceae (Rochalimaea and Rickettsia species) (49). 16S rRNA sequences are now available for all four Rochalimaea species and for Bartonella bacilliformis $(6,11,26,31,33-35,52)$. It should be noted that the Bartonella bacilliformis sequence reported by O'Connor et al. (26) was incorrect and has been corrected (11) and that the results of workers in three laboratories who used the same strain of Bartonella bacilliformis differ by as much as $2 \%(6,11,34)$. Sequence comparisons indicate that the levels of homology among Rochalimaea species are 99.1 to $99.7 \%$ and the levels of homology between Rochalimaea species and Bartonella bacilliformis are 97.9 to $98.8 \%$ (not including data from the incorrect sequence generated by $\mathrm{O}^{\prime}$ Connor et al. [26]). The 16S rRNA sequence data complement the DNA hybridization data that support the hypothesis that there should be a single genus for Rochalimaea and Bartonella species.

A constant and convincing fact from all of the sequence studies described above is that there has been substantial evolutionary divergence of Rochalimaea and Bartonella species from all "true" members of the Rickettsiales. In fact, Rochalimaea and Bartonella species are more closely related to a number of other bacteria, including Brucella abortus and Agrobacterium tumefaciens, than to any rickettsial species.

The available phylogenetic data quite convincingly identify a number of serious taxonomic problems in the Rickettsiales. It is likely that additional taxonomic inconsistencies will be revealed when 16S rRNA sequence data and DNA hybridization data are available for all genera and species. Changes in the classification of the genera Rochalimaea and Bartonella are now warranted on the basis of phylogenetic data. Although the order Rickettsiales is not precisely defined, it is clear that neither the genus Rochalimaea nor the genus Bartonella belongs in this order. Thus, the family Bartonellaceae and the genera Bartonella and Rochalimaea should be removed from the order Rickettsiales. Members of the genus Rochalimaea are most closely related to members of the genus Bartonella and therefore should be transferred from the family Rickettsiaceae to the family Bartonellaceae. While it can be argued that the genera Rochalimaea and Bartonella should remain separate genera, we believe that, in accord with the recommendations of Wayne et al. (46), the members of these taxa are sufficiently related genotypically and phenotypically to merit being in a single genus. Since the names Bartonella and Bartonella bacilliformis predate the name Rochalimaea and the name of its oldest species, Rochalimaea quintana, the name Bartonella should be retained for the unified genus. This means that new combinations for the four Rochalimaea species must be created. Formal taxonomic proposals are made below.

Emendation of the order Rickettsiales (Gieszczykiewicz 1939) Weiss and Moulder 1984. It is proposed that the genus Rochalimaea and the family Bartonellaceae, containing the genera Bartonella and Grahamella, should be removed from the order Rickettsiales. This requires emending the description of the Rickettsiales (56) to exclude motile organisms and organisms that multiply on bacteriologic media. It also reduces the number of families to two, the Rickettsiaceae and the Anaplasmataceae.

Emendation of the family Rickettsiaceae (Pinkerton 1936) Weiss and Moulder 1984. It is proposed that the genus Rochalimaea should be removed from the family Rickettsiaceae. This requires emending the description of the Rickettsiaceae to exclude organisms that are cultivable in cellfree media.

Emendation of the tribe Rickettsieae (Philip 1953) Weiss and Moulder 1984. It is proposed that the genus Rochalimaea should be removed from the tribe Rickettsieae. This requires emending the description of the Rickettsieae (56) by reducing the number of genera to two, the genera Rickettsia and Coxiella.

Emendation of the family Bartonellaceae (Gieszczykiewicz 1939) Ristic and Kreier 1984. It is proposed that the genus Rochalimaea should be transferred to the family Bartonellaceae. This requires emending the description of the Bartonellaceae (36) by integrating portions of the description of the genus Rochalimaea (56) and data for Rochalimaea henselae and Rochalimaea elizabethae, as follows.

Parasites of erythrocytes of humans and other vertebrates and of human cutaneous and osseous tissue. Cells are rod shaped, cocci, or ring or disk shaped, often beaded or filamentous. Greatest cell diameter is less than $3 \mu \mathrm{m}$. Gram negative; aerobic; not acid fast. Strains do not utilize carbohydrates. One species has unipolar flagella. Cultivable on bacteriologic media. Arthropod transmission has been established for many species. Human pathogens include etiologic agents of trench fever, bartonellosis, bacillary angiomatosis $(10,39,40)$, peliosis hepatis, septicemia, and possibly cat scratch disease (32). Animal species, which have been found in erythrocytes of rodents and other vertebrates, are nonpathogenic (48). The type genus is Bartonella Strong, Tyzzer, and Sellards 1915.

Emendation of the genus Bartonella (Strong, Tyzzer, and Sellards 1915) Ristic and Kreier 1984. It is proposed that the genus Rochalimaea should be united with the genus Bartonella. This requires emending the description of the genus Bartonella (36) by integrating portions of the description of the genus Rochalimaea (57) and data for Rochalimaea henselae and Rochalimaea elizabethae, as follows.

Gram-negative, oxidase-negative, fastidious, aerobic rods. One species is motile by means of polar flagella. Best growth is obtained on media containing $5 \%$ rabbit or sheep blood in the presence of $5 \% \mathrm{CO}_{2}$. The optimal incubation temperature varies from $25^{\circ} \mathrm{C}$ (Bartonella bacilliformis) to 35 to $37^{\circ} \mathrm{C}$. Carbohydrates are not utilized. All but one species are pathogenic for humans. Arthropod vectors have been demonstrated for Bartonella bacilliformis, for Bartonella quintana, and probably for Bartonella vinsonii (4). One or more species cause bartonellosis, trench fever, bacillary angiomatosis, peliosis hepatis, septicemia, and perhaps cat scratch disease. The $\mathrm{G}+\mathrm{C}$ contents of the DNAs are 38.5 to $41 \mathrm{~mol} \%$. The type species is Bartonella bacilliformis (Strong, Tyzzer, Brues, Sellards, and Gastiaburú 1913) Strong, Tyzzer, and Sellards 1915.

Description of Bartonella quintana comb. nov. The most recent description of Rochalimaea quintana is that of Weiss and Moulder (57). In addition, Bartonella quintana is oxidase positive as determined by the standard oxidase test or weakly oxidase positive as determined by the Kovacs modification of the standard test (11). Bartonella quintana is pathogenic for humans. It causes trench fever, is an etiologic agent of bacillary angiomatosis (20), and has been isolated 
from patients with human septicemia (58). The $16 \mathrm{~S}$ rRNA gene nucleotide sequence of the type strain, ATCC VR-358, has been deposited in the GenBank data base under accession number M73228 (31). A corrected sequence has been submitted to the GenBank, EMBL, and DDBJ data bases (accession number L01259) (11).

Description of Bartonella vinsonii comb. nov. The most recent description of Rochalimaea vinsonii is that by Weiss and Moulder (57). In addition, Bartonella vinsonii is oxidase negative in the standard oxidase test or weakly oxidase positive in the Kovacs modification of the standard test (11). The 16S rRNA gene nucleotide sequence of the type strain, ATCC VR-152, is deposited in the GenBank data base under accession number M73230 (31).

Description of Bartonella henselae comb. nov. With the following additions, the description of Bartonella henselae is the same as the description given previously (31) for Rochalimaea henselae. Bartonella henselae is pathogenic for humans. It is a major etiologic agent of bacillary angiomatosis $(33,35)$ and of hepatic and splenic peliosis $(58)$. It is a causative agent of septicemia in immunocompromised persons as well as in otherwise healthy persons (58) and may be a major cause of cat scratch disease (32). No arthropod vector has been identified. The type strain is Houston 1 (= G5436 = ATCC 49882); it has a G+C content of $41 \mathrm{~mol} \%$ (11), and its 16S rRNA gene nucleotide sequence has been deposited in the GenBank data base under accession number M73229 (31).

Description of Bartonella elizabethae comb. nov. The description of Bartonella elizabethae is the same as the description given by Daly et al. for Rochalimaea elizabethae (11). No arthropod vector has been identified. The 16S rRNA gene nucleotide sequence of the type strain, ATCC 49927 (= F9251 = B91-002005), has been deposited in the GenBank, EMBL, and DDBJ data bases under accession number L01260 (11).

\section{REFERENCES}

1. Anacker, R. L., T. F. McCaul, W. Burgdorfer, and R. K. Gerloff. 1980. Properties of selected rickettsiae of the spotted fever group. Infect. Immun. 27:468-474.

2. Anderson, B. E., J. E. Dawson, D. D. Jones, and K. H. Wilson. 1991. Ehrlichia chaffeensis, a new species associated with human ehrlichiosis. J. Clin. Microbiol. 29:2838-2842.

3. Anderson, B. E., C. E. Greene, D. C. Jones, and J. E. Dawson. 1992. Ehrlichia ewingii sp. nov., the etiologic agent of canine granulocytic ehrlichiosis. Int. J. Syst. Bacteriol. 42:299-302.

4. Baker, J. A. 1946. A rickettsial infection in Canadian voles. J. Exp. Med. 84:37-51.

5. Bilofsky, H. S., and C. Burks. 1988. The GenBank genetic sequence data bank. Nucleic Acids Res. 16:1861-1864.

6. Birtles, R. J., T. G. Harrison, N. K. Fry, N. A. Saunders, and A. G. Taylor. 1991. Taxonomic considerations of Bartonella bacilliformis based on phylogenetic and phenotypic characteristics. FEMS Microbiol. Lett. 83:187-192.

7. Bratina, B. J., G. A. Brusseau, and R. S. Hanson. 1992. Use of 16S rRNA analysis to investigate phylogeny of methylotrophic bacteria. Int. J. Syst. Bacteriol. 42:645-648.

8. Brenner, D. J., A. C. McWhorter, J. K. Leete Knutson, and A. G. Steigerwalt. 1982. Escherichia vulneris: a new species of Enterobacteriaceae associated with human wounds. J. Clin. Microbiol. 15:1133-1140.

9. Brenner, D. J., S. P. O'Connor, D. G. Hollis, R. E. Weaver, and A. G. Steigerwalt. 1991. Molecular characterization and proposal of a neotype strain for Bartonella bacilliformis. J. Clin. Microbiol. 29:1299-1302.

10. Cockerell, C. J., and P. E. LeBoit. 1990. Bacillary angiomatosis: a newly characterized, pseudoneoplastic, infectious, cutaneous vascular disorder. J. Am. Acad. Dermatol. 22:501-512.
11. Daly, J. S., M. G. Worthington, D. J. Brenner, C. W. Moss, D. G. Hollis, R. S. Weyant, A. G. Steigerwalt, R. E. Weaver, M. I. Daneshvar, and S. P. O'Connor. 1993. Rochalimaea elizabethae sp. nov. isolated from a patient with endocarditis. J. Clin. Microbiol. 31:872-881.

12. Dame, J. B., S. M. Mahan, and C. A. Yowell. 1992. Phylogenetic relationship of Cowdria ruminantium, agent of heartwater, to Anaplasma marginale and other members of the order Rickettsiales determined on the basis of 16S rRNA sequence. Int. J. Syst. Bacteriol. 42:270-274.

13. Dasch, G. A., and E. Weiss. 1977. Characterization of the Madrid E strain of Rickettsia prowazekii purified by Renografin density gradient centrifugation. Infect. Immun. 15:280-286.

14. Devereux, J., P. Haeberli, and O. Smithies. 1984. A comprehensive set of sequence analysis programs for the VAX. Nucleic Acid Res. 12:387-395.

15. Dorsh, M., E. Moreno, and E. Stackebrandt. 1989. Nucleotide sequence of 16S rRNA from Brucella abortus. Nucleic Acids Res. 17:1765.

16. Felsenstein, J. 1985. Confidence limits on phylogenies: an approach using the bootstrap. Evolution 39:783-791.

17. Felsenstein, J. 1989. PHYLIP-phylogeny inference package (version 3.2). Cladistics 5:164-166.

18. Hanson, B. A., C. L. Wisseman, Jr., A. Waddell, and D. J. Silverman. 1981. Some characteristics of heavy and light bands of Rickettsia prowazekii on Renografin gradients. Infect. Immun. 34:596-604.

19. Jukes, T. H., and C. R. Cantor. 1969. Evolution of protein molecules, p. 21-132. In H. N. Munro (ed.), Mammalian protein metabolism, vol. 3. Academic Press, Inc., New York.

20. Koehler, J. E., F. D. Quinn, T. G. Berger, P. E. LeBoit, and J. W. Tappero. 1992. Isolation of Rochalimaea species from cutaneous and osseous lesions of bacillary angiomatosis. N. Engl. J. Med. 325:1625-1631.

21. Kreier, J. P., R. Gother, G. M. Ihler, H. E. Krampitz, G. Mernaugh, and G. H. Palmer. 1991. The hemotrophic bacteria: the families Bartonellaceae and Anaplasmataceae, p. 3994 4022. In A. Balows, H. G. Trüper, M. Dworkin, W. Harder, and K.-H. Schleifer (ed.), The prokaryotes, 2nd ed. Springer-Verlag, New York.

22. Moore, W. E. C., and L. V. H. Moore. 1989. Index of the bacterial and yeast nomenclatural changes published in the International Journal of Systematic Bacteriology since the 1980 Approved Lists of Bacterial Names (1 January 1980 to 1 January 1989). American Society for Microbiology, Washington, D.C.

23. Myers, W. F., and C. L. Wisseman, Jr. 1980. Genetic relatedness among the typhus group of rickettsiae. Int. J. Syst. Bacteriol. 30:143-150.

24. Myers, W. F., and C. L. Wisseman, Jr. 1981. The taxonomic relationship of Rickettsia canada to the typhus and spotted fever groups of the genus Rickettsia, p. 313-325. In W. Burgdorfer and R. Anaker (ed.), Rickettsiae and rickettsial diseases. Academic Press, New York.

25. Myers, W. F., C. L. Wisseman, Jr., P. Fiset, E. V. Oaks, and J. F. Smith. 1979. Taxonomic relationship of vole agent to Rochalimaea quintana. Infect. Immun. 26:976-983.

26. O'Connor, S. P., M. Dorsch, A. G. Steigerwalt, D. J. Brenner, and E. Stackebrandt. 1991. 16S rRNA sequences of Bartonella bacilliformis and cat scratch disease bacillus reveal phylogenetic relationships with the alpha-2 subgroup of the class Proteobacteria. J. Clin. Microbiol. 29:2144-2150.

27. O'Neil, S. L., R. Giordano, A. M. Colebert, T. L. Karr, and H. M. Robinson. 1992. 16S rRNA phylogenetic analysis of the bacterial endosymbionts associated with cytoplasmic incompatibility in insects. Proc. Natl. Acad. Sci. USA 89:2699-2702.

28. Ormsbee, R. A. 1985. Rickettsiae as organisms, p. 15-37. In J. Kazár (ed.), Rickettsiae and rickettsial diseases. Publishing House of the Slovak Academy of Sciences, Bratislava, Czechoslovakia.

29. Oyaizu, H., and C. R. Woese. 1985. Phylogenetic relationships among the sulfate respiring bacteria, myxobacteria, and purple bacteria. Syst. Appl. Microbiol. 6:257-263.

30. Philip, C. B. 1957. Family I. Rickettsiaceae Pinkerton, 1936, p. 
934-947. In R. S. Breed, E. G. D. Murray, and N. R. Smith (ed.), Bergey's manual of determinative bacteriology, 7th ed. Williams \& Wilkins Co., Baltimore.

31. Regnery, R. L., B. E. Anderson, J. E. Clarridge III, M. C. Rodriquez-Barradas, D. C. Jones, and J. H. Carr. 1992. Characterization of a novel Rochalimaea species, $R$. henselae sp. nov., isolated from blood of a febrile, human immunodeficiency virus-positive patient. J. Clin. Microbiol. 30:265-274.

32. Regnery, R. L., J. G. Olson, B. A. Perkins, and W. Bibb. 1992. Serological response to "Rochalimaea henselae" antigen in suspected cat-scratch disease. Lancet 339:1443-1445.

33. Relman, D. A., S. Falkow, P. E. LeBoit, L. A. Perkocha, K.-W. Min, D. F. Welch, and L. N. Slater. 1991. The organism causing bacillary angiomatosis, peliosis hepatis, and fever and bacteremia in immunocompromised patients. N. Engl. J. Med. 324: 1514.

34. Relman, D. A., P. W. Lepp, K. N. Sadler, and T. M. Schmidt. 1992. Phylogenetic relationships among the agent of bacillary angiomatosis, Bartonella bacilliformis, and other alpha-proteobacteria. Mol. Microbiol. 6:1801-1807.

35. Relman, D. A., J. S. Loutit, T. M. Schmidt, S. Falkow, and L. S. Tompkins. 1990. The agent of bacillary angiomatosis: an approach to the identification of uncultured pathogens. N. Engl. J. Med. 323:1573-1580.

36. Ristic, R., and J. P. Kreier. 1984. Family II. Bartonellaceae Gieszczykiewicz $1939,25^{\mathrm{AL}}$, p. 717-719. In N. R. Krieg and J. G. Holt (ed.), Bergey's manual of systematic bacteriology, vol. 1. Williams \& Wilkins Co., Baltimore.

37. Saitou, N., and M. Nei. 1987. The neighbor-joining method: a new method for reconstructing phylogenetic trees. Mol. Biol. Evol. 4:406-425.

38. Schramek, S. 1974. Deoxyribonucleic acid base composition of rickettsiae belonging to the Rocky Mountain spotted fever group isolated in Czechoslovakia. Acta Virol. 18:173-174.

39. Slater, L. N., D. F. Welch, and K.-W. Min. 1992. Rochalimaea henselae caused bacillary angiomatosis and peliosis hepatis. Arch. Intern. Med. 152:602-606.

40. Stoler, M. H., T. A. Bonfiglio, R. T. Steigbigel, and M. Pereira. 1983. An atypical subcutaneous infection associated with acquired immune deficiency syndrome. Am. J. Clin. Pathol. 80:714-718.

41. Storz, J., and L. A. Page. 1971. Taxonomy of the chlamydiae: reasons for classifying organisms of the genus Chlamydia, family Chlamydiaceae, in a separate order Chlamydiales ord. nov. Int. J. Syst. Bacteriol. 21:332-334.

42. Tsuji, K., H. C. Tsien, R. S. Hanson, S. R. DePalma, R. Scholtz, and S. LaRoche. 1989. 16S rRNA sequence analysis for determination of phylogenetic relationships among methylotrophs. J. Gen. Microbiol. 136:1-10.

43. Tyeryar, F. J., Jr., E. Weiss, D. B. Millar, F. M. Bozeman, and R. A. Ormsbee. 1973. DNA base composition of the rickettsiae. Science 180:415-417.

44. Uchida, T., T. Uchiyama, K. Kumano, and D. H. Walker. 1992. Rickettsia japonica sp. nov., the etiological agent of spotted fever group rickettsiosis in Japan. Int. J. Syst. Bacteriol. 42:303-305.

45. van Vliet, A. H. M., F. Jongejan, and B. A. M. van der Zeijst. 1992. Phylogenetic position of Cowdria ruminatium (Rickettsiales) determined by analysis of amplified $16 \mathrm{~S}$ ribosomal DNA sequences. Int. J. Syst. Bacteriol. 42:494-498.

46. Wayne, L. G., D. J. Brenner, R. R. Colwell, P. A. D. Grimont,
O. Kandler, M. I. Krichevsky, L. H. Moore, W. E. C. Moore, R. G. E. Murray, E. Stackebrandt, M. P. Starr, and H. G. Trüper. 1987. Report of the Ad Hoc Committee on Reconciliation of Approaches to Bacterial Systematics. Int. J. Syst. Bacteriol. 37:463-464.

47. Weinman, D. 1957. Family III. Bartonellaceae Gieszczykiewicz, 1939, p. 968-980. In R. S. Breed, E. G. D. Murray, and N. R. Smith (ed.), Bergey's manual of determinative bacteriology, 7th ed. Williams \& Wilkins Co., Baltimore.

48. Weinman, D., and J. P. Kreier. 1977. Bartonella and Grahamella, p. 197-233. In J. P. Kreier (ed.), Parasitic protozoa, vol. 4. Academic Press, New York.

49. Weisburg, W. G., S. M. Barns, D. A. Pelletier, and D. J. Lane. 1991. 16S ribosomal DNA amplification for phylogenetic study. J. Bacteriol. 173:697-703.

50. Weisburg, W. G., M. E. Dobson, J. E. Samuel, G. A. Dasch, L. P., Mallavia, O. Baca, L. Mandelco, J. E. Sechrest, E. Weiss, and C. R. Woese. 1989. Phylogenetic diversity of the rickettsiae. J. Bacteriol. 171:4202-4206.

51. Weisburg, W. G., T. P. Hatch, and C. R. Woese. 1986. Eubacterial origin of chlamydiae. J. Bacteriol. 167:570-574.

52. Weisburg, W. G., C. R. Woese, M. E. Dobson, and E. Weiss. 1985. A common origin of rickettsiae and certain plant pathogens. Science 230:556-558.

53. Weiss, E. 1982. The biology of rickettsiae. Annu. Rev. Microbiol. 36:345-370.

53a.Weiss, E., and G. A. Dasch. 1982. Differential characteristics of strains of Rochalimaea: Rochalimaea vinsonii sp. nov., the Canadian vole agent. Int. J. Syst. Bacteriol. 32:305-314.

54. Weiss, E., and G. A. Dasch. 1991. Introduction to the Rickettsiales and other parasitic or mutualistic prokaryotes, p. 24012406. In A. Balows, H. G. Trüper, M. Dworkin, W. Harder, and K.-H. Schleifer (ed.), The prokaryotes, 2nd ed. Springer-Verlag, New York.

55. Weiss, E., G. A. Dasch, D. R. Woodman, and J. C. Williams. 1978. Vole agent identified as a strain of the trench fever rickettsia, Rochalimaea quintana. Infect. Immun. 19:10131020.

56. Weiss, E., and J. W. Moulder. 1984. Order I. Rickettsiales Gieszczkiewicz (sic) $1939,25^{\mathrm{AL}}$, p. 687-688. In N. R. Krieg and J. G. Holt (ed.), Bergey's manual of systematic bacteriology, vol. 1. Williams \& Wilkins Co., Baltimore.

57. Weiss, E., and J. W. Moulder. 1984. Genus II. Rochalimaea (Macchiavello 1947) Krieg 1961, 162 AL, p. 698-701. In N. R. Krieg and J. G. Holt (ed.), Bergey's manual of systematic bacteriology, vol. 1. Williams \& Wilkins Co., Baltimore.

58. Welch, D. F., D. A. Pickett, L. N. Slater, A. G. Steigerwalt, and D. J. Brenner. 1992. Rochalimaea henselae sp. nov., a cause of septicemia, bacillary angiomatosis, and parenchymal bacillary peliosis. J. Clin. Microbiol. 30:275-280.

59. Winkler, H. H. 1976. Rickettsial permeability: an ADP-ATP transport system. J. Biol. Chem. 251:389-396.

60. Wisseman, C. L., Jr. 1985. Selected observations on rickettsiae and their host cells, p. 167-184. In J. Kazár (ed.), Rickettsiae and rickettsial diseases. Publishing House of the Slovak Academy of Sciences, Bratislava, Czechoslovakia.

61. Woese, C. R. 1987. Bacterial evolution. Microbiol. Rev. 51:221271.

62. Yang, D., Y. Oyaizu, H. Oyaizu, G. J. Olsen, and C. R. Woese. 1985. Mitochondrial origins. Proc. Natl. Acad. Sci. USA 82: $4443-4447$. 